\title{
Leading institutional mechanism of the state regulation and the shadow economy
}

\author{
Olexander Kopylenko \\ National Academy of Sciences of Ukraine \\ Institute of Legislation of the Verkhovna Rada of Ukraine \\ Nesterovsky per. 4, 04053, Kiev \\ Ukraine \\ e-mail: zak_norm@rada.gov.ua \\ Inna Gryshova \\ Institute of Legislation of the Verkhovna Rada of Ukraine \\ Nesterovsky per. 4, 04053, Kiev \\ Ukraine \\ e-mail: rimmagrish@te.net.ua \\ Oleksey Diachenko \\ The Odessa State Agrarian University \\ Panteleymonivska str. 13, 65000, Odessa \\ Ukraine \\ e-mail: oleksa1983.03@gmail.com
}

\begin{abstract}
A world "association" acknowledges that dynamics of the development of the shadow sector becomes a global threat economic security, in this connection with what from the states acceptance of the concerted measures of fight is required against this publicly dangerous phenomenon both on national and on international levels. To deal with these sources, the appropriate mechanisms for regulating the level of development of the shadow economy sector from the state side need to be upgraded. Nevertheless, the development of shadow processes in the economy is due to the fact that their volumes actually do not lead to a clear, systematic control, which leads to the need to improve the priority areas of regulatory control in some kind of cybercrime. Higher education provides an opportunity to consider the investigated issue as an actuality of nautical education, which has important scientific and practical knowledge for introducing changes into the theory and practice of mechanisms of regulatory regulation, namely, the effectiveness of the functioning of state instruments in counteracting the development of shadowing in Ukraine. In the article, the identification of views of both domestic and foreign scientists concerning the content of the contents and the main components of the mechanisms of effective regulation in the field of counteraction to the shadow economy are conducted. It was carried out an analysis of the current level of the shadow sector in Ukraine and identified the basic factors of the domestic economy in the educational stage of the state's development. There are a number of factors that affected the scale of the shadow economy in Ukraine. There was a proposed scientific and methodological approach to the formation of an effective integration mechanism for counteracting the shadow economy in Ukraine. It was the necessity to unify and consolidate formally obligatory inclusion of the coordination and advisory bodies to prevent the shadow of the country members of the public, which in turn will contribute to the balancing of public power and public foundations in the context of establishing state mechanisms of combating the shadow economy. The revision of the conducted report makes it possible to apply the innovative recombination on the effective functioning of the mechanisms of the effective regulation of the opposition to the development of the shadow economy sector.
\end{abstract}

\section{Introduction}

In modern globalized world, in any state, despite of the level of development its socio-economic and legal systems, the activation of the shadow economy leads to the spread of corruption, means and methods of criminal competition. Activation of the shadow economy leads to corruption, criminal means and methods of competition, the reorientation of economic subjects in the interest of criminal organizations, and as a result - to significant adverse changes in state economic operation of the whole system and problems of state regulation of the shadow economy as a whole (Mostenska 2015; Bychkova et al. 2018).

According to Atamchuk (1997), the mechanism of the state regulation is a complex system of the state bodies organized in accordance with the established principles for the realization of the tasks of the state 
administration (Atamanchuk 1997). According to Vergun and Maslak (2009), the mechanism of the modern state is imbued with the only legally established principles, based on the distribution of power and the availability of the necessary material appendages of the system of state authorities and local self-government, which performs the tasks or functions of the state or ensures their implementation (Kuzmin 2015). The mechanism of the state is based on certain principles. They can be divided into general, belonging to the mechanism of the state as a whole, and partial, whose action extends only to separate parts of the state machinery, certain bodies or groups of bodies (Vergun and Maslak 2009; or Moyseyenko and Ryvak 2016). Vorotin (2009) believes that the mechanism of effective regulation should be disbanded as a complex system of control of the administration, which ensures the formation of a responsible resolution or the adoption of it and its rationalization. The mechanism of the state administration is a single system, which in its turn consists of specific administrative mechanisms (Vorotin 2002).

Korotych (2005), as a part of the state mechanisms of management, identifies specific government mechanisms of governance, mechanisms for implementing the state administration process, as well as mechanisms for the formation and interaction of constituent systems of the state administration. According to the researcher, the specific mechanisms of governance (in particular, the state) are a certain tool for carrying out targeted transformations; it is a set of means, methods, levers, through which the subject of management affects the object of management to achieve a certain goal. Each particular mechanism of governance is, first of all, a set of interconnected administration methods through which the practical influence of the state on the social life of people is carried out to ensure the achievement of a specific goal that will contribute to the country's development in the chosen strategic direction, while adhering to a number of defining principles (Korotych 2005).

In the modern conditions, the development of a national economy is characterized by the prominence of such a wide range of socio-economic relations that encompass unregistered, unregulated and illegal activities of economic entities (Strielkowski and Čábelková 2015). Such relations are called the shadow, the size of which grows every year, which has a significant effect on the general socio-economic processes that are taking place in the state. The foreign researchers of the shadow economy did not have a single definition of this concept (Strielkowski and Čábelková 2016). For Gutmann (1977) and Feige (1979), the "shadow economy" (they called it "underground") is an unaccounted part of GDP, which should be added to economic activity, then for Tanzi (1982), the "shadow economy", which he also calls "underground", means the income that is not fixed by the tax service. Tanzi (1982) himself pointed out for such discrepancies in the definitions, explaining the difference in the obtained indicators of the estimation of the shadow economy. Kolomer V'yadel (1999) considers the shadow economy from the same position.

By Augustine's definition, "the shadow economy occurs when the actions of the power and regulatory structures of the state, individuals or their groups conflict with objective economic laws" (Avgustyn 2014). According to Leonova (2015), the shadow economy is relations between separate individuals or their groups and institutional units in relation to the production, distribution, redistribution, exchange, and the coping of the material funds and services, whose results for whatever reason cannot inspire official statistics and whose volume is not included to indicators of macroeconomic dimension (Leonova 2015).

According to Mazur (2014), under the shadow economy it is expedient to consider difficult social and economic process which is presented by a totality uncontrollable and unregulated as illegal and corresponding lawful, however, the immoral economic relations between the subjects of managing concerning receiving over profit by its concealment and evasion of taxes (Mazur 2014).

We believe that the shadow economy - a complex phenomenon of the socio-economic system of the state, which is represented which is represented by a totality of uncontrolled and unregulated economic relations between the economic entities in the direction of obtaining illicit income, which, accordingly, is concealed from the payment of taxes. The results of the conducted research gave an opportunity to substantiate the content and essence of the mechanisms of state regulation of the counteraction to the development of the shadow sector by introducing them as an integrated system of successive actions of state authorities in cooperation with public institutions, which have a pronounced partnership nature of interaction, openness and transparency of the relevant relationship, mutual responsibility and consist of specific mechanisms (organizational, economic, political, legal, informational-analytical, motivational, etc.), the realization of which is aimed at ensuring a balanced and effective state policy in this area.

\section{Materials and methods of research}

The methodological basis of the study is the accumulation of both scientific and practical methods. In the formation of a conceptually-categorical apart, the use of the methods of analysis, association and scientific abstraction, and synthesis. In developing proposals for the implementation of the mechanisms for the effective regulation of the opposition to the shadow economy sector, the use of logical constraints and system-structured method, which involves several stages: 
1) the problems of the formation of the inquisitorial mechanism of the effective regulation of the opposition to the shadowing of the economy are substantiated;

2) identified by the clandestine mechanism of the effective regulation of shadow processes in the country's economy and their counteraction;

3 ) the grouping of the clandestine mechanics is in accordance with their coordination with existing scientific theories;

4) the development of clear connections and the relationship between the eminences, structures and objectives of the mechanism, with the aim of identifying a concessional construct to the development of the institutional component of the mechanism of effective control of the process of counteraction to shadow in Ukraine.

\section{Results and discussion}

The levels of shadow economy in Ukraine have been such a development and spread that they were able to influence the structure and GDP of the country in auspicious ways, affecting its official character, and adversely affect the national security and the democratic development of society. The development of effective sources of the state in counteracting the development of shadow processes in the economy involves a comprehensive study of the existing problems, the coordination of problems, the identification of the mechanisms of their interaction and counteraction to development. There is an urgent need to account for shadow processes in the economy of the country with a view to conducting an economic analysis of micro and microcosms, ensuring the formation of the corresponding sources of the state in relation to the regulation of market relations and effective normative and legal support.

The problems of the economic shadowing exist in almost all the countries. According to the Financial Action Task Force on Money Laundering (FATF) of the International Group for the Development of Fighting Money Laundering, the size of the shadow economy in the highly developed countries accounted for $17 \%$ of GDP, with a pre-eco economy of $20 \%$ of GDP, in developing countries , $40 \%$ of GDP, while it is believed that the optimal level of shadowing is 10-12\% of the official GDP, $20 \%$ is a critical level for the fiscal economy, and if more than $40 \%$ is catastrophic level (Varlamova 2013).

The level of shadowing of the economy is closely related to the socio-economic development of the state, guaranteeing national, economic security. Analysing the dynamics and reasons of changes level of shadowing in different periods of the development of country you need to remember, during a persistent economic development, the shadow sector acts as a system indicator of the ineffectiveness of state regulation, which shows the need to use administrative regulatory tools, and unfavourable business conditions, an instrument for the enrichment of individual market players during the period of economic crises and interfere with the image of the state in a gross environment etc. In the course of the study, it was revealed that the proportional dependence of the level of economic security on the intensity of the manifestation of shadow relations in Ukraine was clearly reversed (Fig. 1).

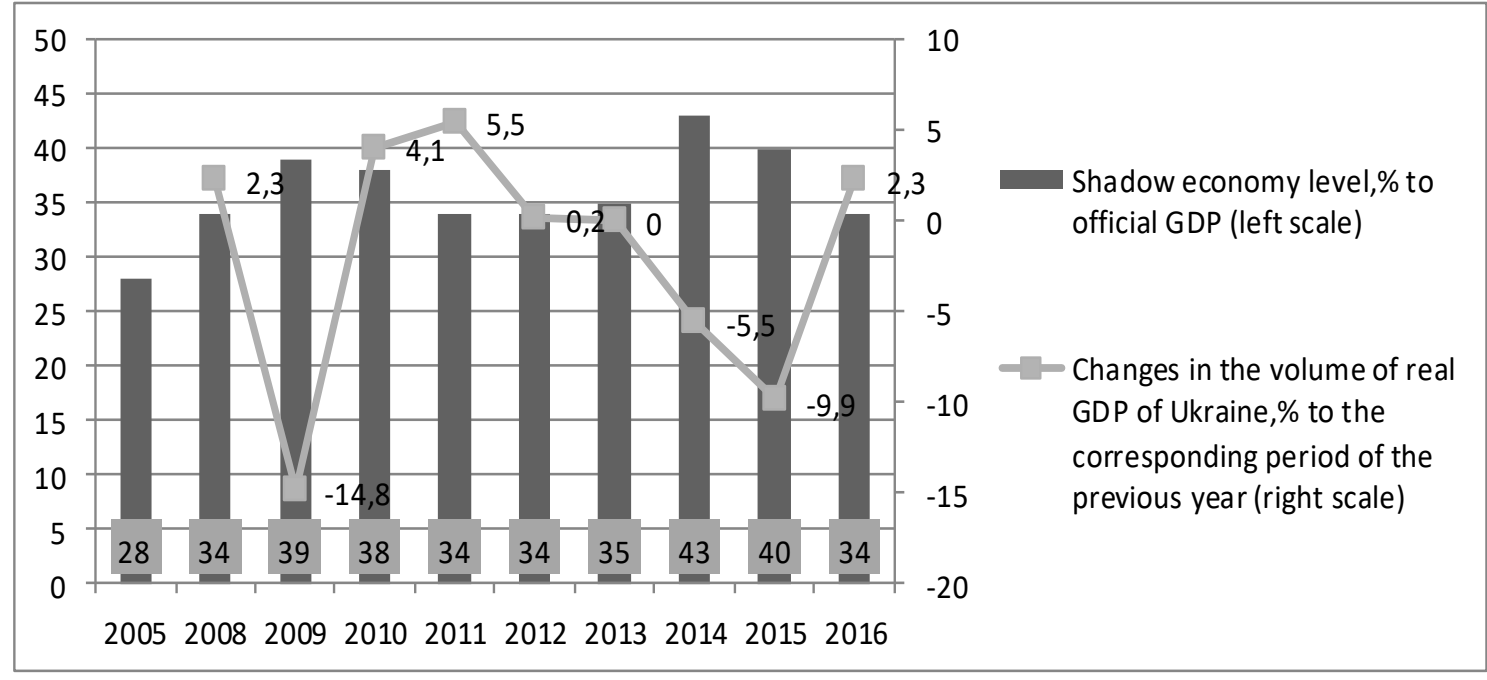

Fig. 1. The economic crisis in Ukraine (in\% of the official GDP) and the rates of decline / decline in the level of real GDP (in\% to the corresponding period of the previous year)

Source: Ministry of Economic Development and Trade of Ukraine (2016) 
Taking into account that for determining the complex level of the shadow sector of the Ukrainian economy, the definition of an integral indicator is characteristic, the method of calculation of which is based on separate different methods (each of which covers a certain area of the macroeconomic level with a correspondingly different part in it of the illegal sector), they showed different meanings in the investigated period.

According to Table 1, only one method of "loss-making enterprises" demonstrated a reduction of the share of (Tanzi 1982) the shadow economy by $-4.0 \mathrm{pp}$ for the entire study period. In addition, since the beginning of 2009 , the size of the shadowing calculated by this method was the lowest compared to other components of the integral indicator.

As of the end of 2016, the absolute size of the shadow segment in Ukraine by the method of "lossmaking enterprises" was $20.0 \%$ - almost 2 times lower than the alternative data obtained through the simulation of "DYMIMIS", and its average index to the integral value for 2013 -2016 gg. was 0.68 . In the view of the above-mentioned facts, it should be concluded that the level of unprofitability of enterprises is a rather artificial indicator in modern economic conditions, based on obviously unwarranted assumptions. Therefore, further application of this method is considered too questionable, and therefore inappropriate.

Table 1. Estimation of the share and level of shadow economy of Ukraine with differentiated methods by years, $\%$ from the official GDP

\begin{tabular}{|c|c|c|c|c|c|c|c|c|c|c|}
\hline \multirow[b]{2}{*}{$\begin{array}{l}\text { The method of } \\
\text { determination }\end{array}$} & \multicolumn{8}{|c|}{ Years } & \multirow{2}{*}{$\begin{array}{c}\text { The } \\
\text { average } \\
\text { meaning } \\
\text { for the } \\
\text { years } \\
2005- \\
2016\end{array}$} & \multirow{2}{*}{$\begin{array}{l}\text { The index } \\
\text { average } \\
\text { meaning of the } \\
\text { method by } \\
\text { the integral } \\
\text { indicator } \\
\text { (average) } \\
\text { for } 2013- \\
2016\end{array}$} \\
\hline & 2005 & 2007 & 2009 & 2011 & 2013 & 2014 & 2015 & 2016 & & \\
\hline $\begin{array}{l}\text { The method of } \\
\text { "population } \\
\text { spending-retail } \\
\text { turnover" }\end{array}$ & 46,5 & 38,0 & 45,0 & 48,0 & 51,0 & 58,0 & 57,1 & 50,0 & 49,2 & 1,42 \\
\hline Electrical method & 28,0 & 27,0 & 35,0 & 29,0 & 30,0 & 38,0 & 35,0 & 31,0 & 31,6 & 0,88 \\
\hline $\begin{array}{l}\text { Monetary } \\
\text { method }\end{array}$ & 25,0 & 26,0 & 40,5 & 26,3 & 23,2 & 33,0 & 30,3 & 27,2 & 28,9 & 0,75 \\
\hline $\begin{array}{l}\text { The method of } \\
\text { lossmaking } \\
\text { enterprises }\end{array}$ & 24,0 & 24,0 & 31,0 & 25,0 & 27,0 & 31,3 & 26,2 & 20,0 & 26,0 & 0,68 \\
\hline $\begin{array}{l}\text { Professor's } \\
\text { assessment } \\
\text { Friedrich } \\
\text { Schneider } \\
\end{array}$ & 46,8 & 47,1 & 41,5 & 40,4 & 39,5 & 46,5 & 47,1 & 41,4 & 43,8 & 1,15 \\
\hline $\begin{array}{l}\text { Estimation by the } \\
\text { methodology of } \\
\text { the State } \\
\text { Statistics } \\
\text { Service }\end{array}$ & 18,1 & 15,5 & 16,1 & 16,0 & - & - & - & - & - & - \\
\hline $\begin{array}{l}\text { The integral } \\
\text { indicator of the } \\
\text { shadow economy }\end{array}$ & 28,0 & 34,0 & 39,0 & 34,0 & 35,0 & 43,0 & 40,0 & 34,0 & 35,9 & 1,0 \\
\hline
\end{tabular}

Source: Ministry of Economic Development and Trade of Ukraine (2016)

Given these trends of domestic shadow during the 2005-2016, the following should be noted:

- during the period in question it was observed the rising level of shadow economy by $+4.0 \mathrm{pp}$. as of 2016, to mark $34.0 \%$ of the official GDP, with an average meaning of 35.9\%. To positive trends of the amount of shadow manifestation should include the reduction of its integral index by -4.0 and $-9.0 \mathrm{pp}$ against the crisis in 2009 and 2014;

- it is determined that the real volume change of GDP in Ukraine has a direct return from the level of development of the shadow sector. Accordingly, in the period of the economic crisis and the rising level of shadowing in 2009 and 2014-2015 observed the reduction of GDP by -14,8, -5,5 and -9,9\% the corresponding period of the previous year, with its subsequent stabilization to the level $2.3 \%$ in 2016 .

In turn, the reduction of the level of shadow economy is constrained by still unresolved problems, which have a negative impact on the indicators of the country's economy as a whole. The shadow economy has well- 
defined socio-economic roots, which are closely linked to the causes of economic crime. The key factors in the shadowing of the national economy at the time of the development of market relations in the country can highlight the following: 1. Ineffective state regulation of the economy the lack of confidence - of business to the state and the state to business, high bureaucratization, imperfect institutional and regulatory support. 2. Inefficient tax system (large and unfair tax burden, in which fiscal function plays a decisive role), increasing the share of unprofitable enterprises, a low level of payment discipline, instability and imperfection of tax legislation, the lack of knowledge of this legislation, legal insecurity of taxpayers, etc. 3. The labor market problems are related to low economic incentives to the official employment of employees, rising levels of unemployment and depreciation of labour costs. 4. Ineffective monetary and credit policy, which is opaque and refinancing of commercial banks and the installing a flexible exchange rate, active activity of the state in the lending market, an increase in the issue of government bonds for the revenue part of the state budget, which contributes to the concentration of capital around illegal operations and the increase of percentages. 5 . Imperfection of the budget system, low control over the use of budget funds, chronic budget deficit, which causes a continuous reduction of public expenditures, the destruction of social, legal and defence infrastructure and almost continuous inflation. 6. High level of monopolization of the domestic market. 7. Imperfection of the law enforcement and judicial systems, in order to establish an effective legal program for the struggle with organized crime. 8. The corruption of state power structures, control services (tax inspection, sanitaryepidemiological control, fire safety, etc.), in which a merger of business and government, is observed lobbying own interests by business subjects in the state institutions. 9. The lack of an investment alternative to "shadow" capital, which is expressed in the form of more effective forms of economic activity that ensure the survival of economic subjects in crisis conditions. 10. The level of general crime. The criminal environment is one of the areas of development of economic crime and, accordingly, the shadow sector, etc.

In the view of the above, mentioned facts, we consider the false approach that the main problems and causes of shadow processes (evasion, non-payment, etc.) lie only in the economic entities, thus excluding the shortcomings of the current system of the state regulation of the economy. Concerning the establishment of mechanisms of state regulation of important factors affecting the scale of the shadow economy are: the inability of the state to provide a constructive reform of economic relations and to form a civilized socially oriented market economy system; the unreadiness of the population and the appropriate business entities to legal activity in the conditions of formation of market relations; miscalculations in the activities of law enforcement agencies; purposeful activity of a criminal world that pursues its specific corporate interests in the field of economics (Gryshova et al. 2017).

The results of the conducted research give reason to assert that the level of shadow economy of Ukraine with different methods of their definition is extremely high and exceeds the maximum permissible threshold value. Such a situation adversely affects the national interests and the social and economic security of the country. Therefore, the improvement of the counteraction mechanisms to the shadow economy, of course, may be one of the most important priority directions of state regulation in Ukraine.

The foregoing helped to determine the directions of the methodological approach to the formation of a state regulation mechanism for counteraction to shadow processes in Ukraine, with the distinction of its basic constituents: institutional and managerial, political and legal, social and economic, social and public, and ethical and psychological, considering of that the greatest effectiveness the society will receive in the case of not a single independent application of one or another listed constituent mechanisms in one or another area of public policy ,in the case of their synergetic combination in a single complex institutional mechanism to prevent the development of the shadow national economy, regulated by the National Strategy of counteracting the shadow economy, and is the basic tool of both national, regional and local policies of shadow economy (Fig. 2).

Based on the foregoing results of the research, can conclude that such a basic characteristic of the institutional mechanism for regulating the processes of counteracting the shadow economy, as its permanence. That is, depending on the content of the implemented function will change the composition of system elements, which interact, the controllers, implementing various measures in the investigated sphere will change.

Proceeding from the foregoing, it is worth to emphases the need to orient the subjects of the institutional mechanism of counteraction to the shadow economy to the need for obligatory accounting and application in the implementation of such activities of the special principles enshrined in regulatory legal acts. In turn, given the key role of local authorities in the field of counteraction to shadowing, it is seen as a logical complement to formalized principles like the principle of "checks and balances", which is to be applied at all levels of the state power and in the part of interaction with the institutions of the civil society (as opposed to, for example, the principle of separation of powers, focused mainly on the functioning of the state power); the principle of functional certainty, aimed at systematization and rectification of competence not only of state authorities, other state bodies, which have the competence to counter the shadow economy, but also local self-government bodies and other state institutions of civil society; the principle of combination of formally defined and initiativeoriented interaction, aimed at stimulating the involvement in the sphere of counteraction to the development of 
the shadow economy both organizationally-formed, and potentially effective subjects as well as in the absence of special regulatory legal systems (Gryshova and Shestakovska 2017).

Consequently, such a systemic problem as counteracting shadowing requires an appropriate comprehensive toolkit and a comprehensive mechanism for combating it, which involves joint coordinated systemic actions of representatives of six public institutions - the state executive; local self-government bodies; law enforcement agencies, including courts; business; civil society and the media as the "fourth branch of the government".

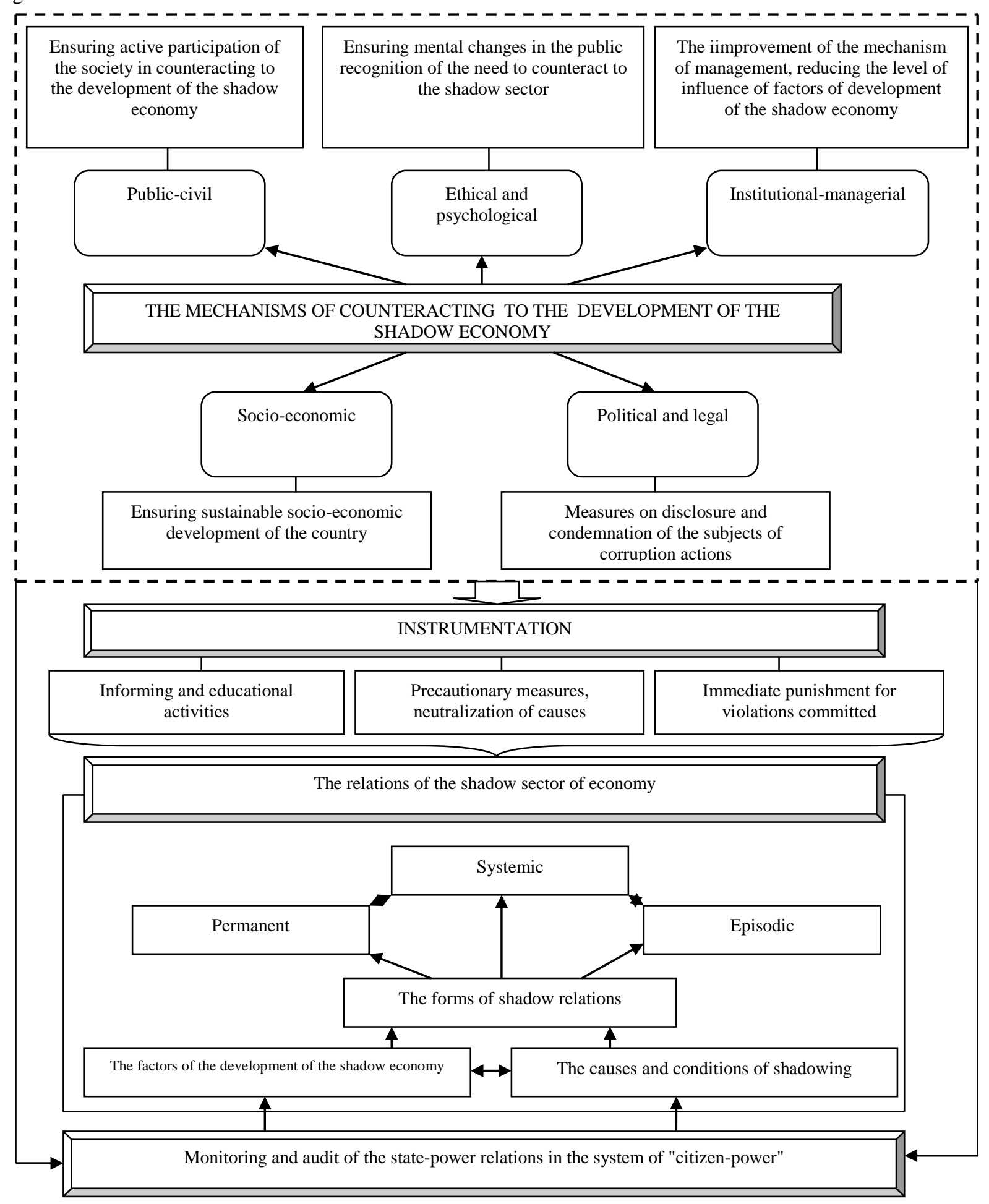

Fig. 2. Methodological construct of the institutional mechanism of the state regulation of the process of counteracting to the development of the shadow economy

Source: Own results 
In our opinion, the general policy of the state in regulating the processes of counteraction to the shadow economy of the outspoken entities in the program-objective dimension should combine three strategic directions:

1) strategies of public awareness, which consist in general audit and monitoring of the situation and the improvement on these grounds, strategies for counteracting development of the shadow economy; civil enlightenment as for fighting the shadowy economy; free access to the information and independent media;

2) warning strategies, the essence of which lies in the formation of transparency of authorities; active involvement of civil society institutions in counteracting to the development of the shadow economy; the reduction of state interference in business and society affairs; the adoption of codes of ethics for bureaucrats, entrepreneurs the reduction of administrative barriers;

3) the strategy of inevitable retaliation, which envisages increasing of professionalism and the effectiveness of the disclosure of corruption crimes by the security forces; the formation of a strong and independent judiciary; strict implementation of the law; public examination of normative-legal and statemanagement decisions; citizens' access to legal assistance and protection.

The substantiated methodological approach provides grounds for asserting that the situation that has emerged requires not only the creation of new approaches to counteract the shadow economy at the national level (in terms of exercising the powers of the competent authorities and officials regarding the provision of the state policy of counteracting the development of the shadow economy), but also a steady attention to the specifics of the activities of the bodies of the Municipal Government.

This is due to the fact that the normative and legal regulation in the sphere of information is not only the normative acts of the agencies of the government, but also the legal measures.

At the same time, from reviewing some achievements in this sphere (adoption of targeted programs, formalization of expert examination of draft legal acts), it will loyally support such directions of organizational and normative creation activities of competent bodies of the Municipal Self-Government: optimization and adoption of new legal acts regarding the resistance of the shadow economy, in particular, in the bodies of local self-government; organization and effective implementation of activities to ensure compliance with the law on preventing inform at the local level by civil and state control institutions; approval and implementation of regional programs for the prevention of informal at the local level; informatization of the process of placement and ensuring the direct access to certain laws and specific in normative-legal acts of the relevant statements of prospective individuals and members of their families; raising the effectiveness of the functioning of the income control systems of the specified assets; improvement of the organization of the organs of the public administration and the fulfillment of the functions of state administration, as well as the normative and pragmatic review of the indicated pro-cycles (for example: the identification of structural subdivisions and property rights, which are characterized by corruption risks); optimization of the monetary policy at the municipal level; raising the level of informativeness of the information on the activities of the organs of the Ministry of Foreign Affairs and measures to counteract the tension of the economy (for example, in the realization of anticorruption support and professional education); Improvement of the mechanism of the order by state property and budget funds, etc.

The results of the study call for the systematization and formal consolidation of the provisions for the inclusion of members of the public in the composition of coordination and advisory bodies and the prevention of informal (the use of specific territorial formations) in an amount not less than one-third of the total number of its members, subject to the availability of special (legal) education (professional) skills) is not less than half of them. Of course, such a requirement is to allow to balance public-power and civil positions in activities related to the resistance of the shadow sector to the level of local self-government on the basis of mutual control, taking into account the achievement of the reality of the right to take action in the implementation of anti-corruption measures, the effectiveness of commissioning the powers of the bodies of state power and, as a consequence, the resolution of the state's strategic tasks regarding the control of the level of shadow 1.

That is why they require a significant shift from the part of the competent organizations and the two sides of the two basic directions of optimization of the institutional support of the mechanism of effective regulation of counteraction to the shadow economy. In the first place, this corresponds to the normalization of the law. In addition, we have to open the possibility of non-operative organizational and organizational optimization of the intrinsic methods of ultra-modern mechanism. In this connection, the actuals represent the exact and exact information of the state of affairs, as well as the minimization of the conditions for the functioning of the shadow sector in the quatrains of the non-consecutive agreement of the governing bodies of the State and its citizens. In the actual production process, it is possible to create the creation of specialized incitements, which contribute to the shortening of manifestations of shadow.

\section{Conclusions}

The justified necessity of the formation of a new conceptual constructor before the functioning of the mechanism of state regulation of the process of resisting the shadow processes in the economy of the country which foresees the general coordinated systemic actions of the representatives of the public institutions (e.g. state executive 
bodies, local self-government bodies, power bodies including civil society, state society, and means of mass information), the interaction of which in the programmatically measured measurement unites the key strategic directions regarding the general awareness, warning and responsibility in the resistance to the development of the shadow economy. It is ascertained that the institutionalized mechanism of shadow prevention provides for: from the standpoint of the organizational relationship between the state-proving institute and the institution of civil society, an internal institutional mechanism for the development of the development of the tine economy is created.)Moreover, the levels of a certain system are separated only technically with the aim of optimal their citation, and in practice, are closely interconnected, and from the standpoint of the properties of the eminent cluster, they are the only organizational and propagandistic phenomenon; in an acute way to ensure the effective implementation of activities in relation to counteracting the development of the shadow economy, a representative organization of territorial formation, called for the direct solving of the tasks of the local selfgovernment and for the purpose of solving the problems of the prosecutors, is the key among all the organs of the mass government.

\section{References}

Atamanchuk GV, Teory ya gosudarstvennogo upravleny`ya [Theory of Public Administration], $1^{\text {st }}$ edn. (Legal literature, Kiev, 1997), 400 p.

Avgusty`n RR (2014) Formuvannya insty`tucial`nogo mexanizmu regulyuvannya tin`ovogo sektoru ta ekonomichnogo zrostannya [Formation of the institutional mechanism for regulation of the shadow sector and economic growth]. Scientific works of DonNTU 3:185-189.

Bychkova S, Makarova N, Zhidkova E (2018) Measurement of information in the subsystem of internal control of the controlling system of organizations of the agro-industrial complex. Entrepreneurship and Sustainability Issues 6(1):35-43. doi: 10.9770/jesi.2018.6.1(3)

Feige E (1979) How big is the irregular economy? Fueling 22(5):5-13.

Gryshova IYu, Shestakovska TL (2017) The Economic Measurement of Convergence of Institutional Impact on the Sustainability of Development of Domestic Enterprises. Scientific Papers of the Legislation Institute of the Verkhovna Rada of Ukraine 5:61-66.

Gryshova IJu, Voronzhak PV, Shestakovska TL (2017) The implementation of the principles of consumerism in the strategy of the development of business. Scientific bulletin of Polissia 2(10):41-48.

Gutmann P (1977) The Subterranean Economy. Financial Analyst Journal 33(6):26-34.

Kolomer V'yadel D A (1999) The shadow economy and the theory of solidarity work. Latin America 4:53-59.

Korotych OB (2005) Metodologichni zasady` derzhavnogo upravlinnya regional`ny`m rozvy`tkom [Methodological principles of state management of regional development]. Theory and practice of public administration 3(12):316

Kuzmin E (2015) Uncertainty Cyclicity and Projectionness. International Journal of Applied Engineering Research 10(17): 37783-37791

Leonova OO (2015) Umovy` ta zakonomirnosti formuvannya tin`ovoyi ekonomiky`v Ukrayini [Conditions and regularities of the formation of the shadow economy in Ukraine]. Development management 2(180):42-49.

Mazur OA (2014) Tin`ova ekonomika v Ukrayini: pry`chy`ny`, formy` yiyi proyavu ta obsyagy` [Shadow economy in Ukraine: causes, forms of its manifestation and volumes]. Bulletin of Dnipropetrovsk University 8(2):70-77.

Ministry of Economic Development and Trade of Ukraine (2016). The general tendencies of the shadow economy in Ukraine. http://www.me.gov.ua/ Accessed 28 Aug 2018

Mostenska T (2015) Informal market as a result of shadow economy. Czech Journal of Social Sciences, Business and Economics 4(2):23-29. doi: 10.24984/cjssbe.2015.4.2.3

Moyseyenko I, Ryvak N (2016) Indirect taxes in the mechanism of state regulation. International Economics Letters 5(2):63-71. doi: 10.24984/iel.2016.5.2.4

Strielkowski W, Čábelková I (2016) Barriers to entry and economic growth in transition economies. Economic Computation \& Economic Cybernetics Studies \& Research 50(2):41-58. doi: 
Strielkowski W, Cábelková, I (2015) Religion, culture, and tax evasion: Evidence from the Czech Republic. Religions 6(2):657-669. doi: 10.3390/rel6020657

Tanzi V (1982) Second (and More Skeptical) Look at the Underground Economy in the United States. The Underground Economy in the United States and Abroad. Lexington, Massachusetts: Lexington Books.

Varlamova IV (2013) Riven` tinizaciyi ekonomiky`: nacional'ni ta svitovi tendenciyi [The level of shadowing of the economy: national and world trends]. Economy and Region 4(11):58-63.

Vergun MG, Maslak PV, Derzhavne upravlinnya ta derzhavne regulyuvannya ekonomiky [Public administration and state regulation of the economy], $1^{\text {st }}$ edn. (Zhytomyr, Ruta, 2009), 147p.

Vorotin VYe, Makroekonomichne regulyuvannya $v$ umovax global`ny`x transformacij [Macroeconomic regulation in the conditions of global transformations], $1^{\text {st }} \mathrm{edn}$. (Kiev, UADU, 2002), 392 p. 